\title{
An Investigation of the Relationship between Motivation and Job Satisfaction of High School Principals in Kirinyaga County, Kenya
}

\author{
Severina Wambeti Njagi \\ School of Education, Mount Kenya University \\ severinawambetinjagi@yhaoo.com
}

\author{
Doi:10.5901/mjss.2014.v5n5p
}

\begin{abstract}
Literature seems to suggest that there is a high state of job dissatisfaction among Principals and teachers in Kenyan Secondary Schools (Okumbe, 1998). They are dissatisfied with such job factors (aspects) as school administrative and management policies, interpersonal relations, workload, status and recognition in the society, available promotion opportunities and their relationship with the employer (Emulole, 1994). Considering the fact that teachers are the ones entrusted with the task of imparting knowledge and skills to the youth who are later absorbed in the economy, it is imperative that their work be facilitated by the school administration. In its sinister terms, low job dissatisfaction lurks behind absenteeism and employee turnover. It may also be part of grievances, low productivity, disciplinary problems, and organizational difficulties. This is supported by Siringi, (1999) who observes that high levels of indiscipline in secondary schools and drug abuse had led to poor academic standards among students due to poor school management. Specifically and in Kirinyaga County there is a high level of job dissatisfaction amongst the principals in the County. According to a report on causes, effects and remedies of indiscipline in high schools in Central Province where the county is situated and compiled by the executive secretary Provincial Education Board, the high rates of strikes and poor academic performance could be related to low job satisfaction among Principals and may result to other organizational difficulties. Hence, this paper examined the level of Principals' satisfaction with administrative workload, salary, recognition, job security, interpersonal relations, working environment and promotion, and to investigated the relationship between them.
\end{abstract}

\section{Background of the Study}

Before Kenya's independence in 1963, little emphasis was placed on education of African children. Seventy per cent of the financial resources devoted to formal education was spent on developing educational facilities for the colonial masters' children. Most Africans did not join secondary schools but attended independent schools that offered education up to primary level (Republic of Kenya, 1965 - (Ominde Report). Only a few Africans went up to standard eight (Sifuna and Otiende, 1994). The few secondary schools that catered for the educational needs of Africans were run by missionaries. Examples of these missionary-run institutions include Alliance, Maseno, Mang'u (Kabaa) and Kagumo where for a long period of time the emphasis was on religion and hard manual work "to remove the laziness from the Africans", while higher educational institutions were unheard of. The few who completed the overseas Cambridge certificate of education successfully proceeded to Makerere in Uganda for university education while the rest went abroad.

At independence, Africanization of formal education sector was strengthened. This was aimed at Africanizing the formal employment sector that was occupied mainly by the Whites and a few Asians republic of Kenya - (1964 Ominde report). Hence, many primary and secondary schools were started to fill these gaps. Practically, every student who successfully completed ordinary level education ('O' Level - Form Four) was eligible to wage employment in the modern sectors of the economy (Republic of Kenya - Gachathi Report, 1976). In spite of the expansion of the education sector through self-help, 'harambee' spirit, few teachers were employed by the Government and the parents shouldered the burden of paying the teachers in the schools they had started. The Teachers Service Commission (TSC) did not even second Principals to these "harambee schools" (schools started and developed by the community) leaving the school committees and Boards of management (BOM) to employ them. Besides, the low pay packages, Principals in "harambee" schools were still faced with the challenge of high student population with poor academic abilities in general and frequent cases of indiscipline (Madera, 1995).

In 1988, it was recommended that the Government takes up the entire responsibility of employing teachers while the local communities took up the role of providing physical facilities to schools through the cost-sharing policy (Republic of Kenya 1988, Kamunge Report). In spite of being under the TSC salary scale, the Principals have continued to face 
diverse challenges. These challenges were aggravated by the remodelling of the education system from seven years of primary, four years of secondary, two years of university to eight years of primary, four years of secondary and four years of university popularly known as the 8-4-4 system of education. This meant an increase in administratrative and instructional challenges (Madera, 1995) let alone the means of motivating the teachers running these schools.

The advocates of the 8-4-4 system of education argue that this system is suitable in meeting economic growth and development of the country. This may be plausible since education is a major factor that has contributed to economic development of most industrialized countries. Hence most developing countries allocate a large percentage of their national budget to education. High investment in education leads to fast industrial growth of a country (Mbugua, 1988).

In Kenya, for instance, the total expenditure on education went up considerably by 11.8 per cent from K£1480.9 million in 1995/96 to K£1655.9 million in 1996/97 fiscal year. General administration and planning had the highest share of the recurrent expenditure estimate accounting for 79.5 per cent of the total recurrent expenditure. The high allocation on administration and planning is attributed to teachers' salaries (Republic of Kenya, 1997). Members of the public and the government, therefore, expect high future returns from the education system (Mbugua, 1998).

Secondary school Principals therefore being the principal administrators of these institutions need to satisfy expectations of the public and the government. However, there have been cases of Principals' mismanagement of school finances. It can be argued that one of the causes of Principals' misappropriation of school finances could be linked to the little salary they get compared to other administrators in equivalent positions in the private sector. It could also be linked to lack of management training as the TSC lacks a serious staff development policy. These are some of the causes of job dissatisfaction due to lack of motivation (Maslow, 1959)

Considering, the foregoing challenges and the fact that the school structure is so restricted offering limited chances of promotion, investigation of the Principals' level of job satisfaction is imperative. This is because the efforts put in a job should be perceived to be equivalently balanced with the benefits. Are these benefits perceived to be satisfying by the Principals with specific relation to the salary, promotion, job security, working conditions, interpersonal relations and work environment among others?

Motivation results from physiological or psychological deficiency or need that activates behaviour or a drive that is aimed at a goal or incentive (Okumbe, 1998). Hence, the Teachers Service Commission should create an environment that will facilitate the alleviation. To add to this, job satisfaction results from the employees' perception of how well the jobs they perform give them satisfaction which they view as important to both themselves and the organization (Herzberg 19). Hence, the secondary school Principals must be able to achieve both their individual goals and organizational objectives.

\section{Theories of Motivation and Job Satisfaction}

\subsection{Maslow's Theory of Human Motivation}

This theory was developed from clinical observations. In his work, "Motivation and Personality", Maslow (1954) posited five basic needs namely: physiological, safety, security, belonging, self-esteem and self-actualization. He postulated that these five needs are related to each other in hierarchy, with physiological needs, being lowest on the scale and selfactualization being the highest in the hierarchy. As lower needs are satisfied, higher level needs are activated. The degree of satisfaction tends to decrease as one moves up the hierarchy. Needs that are satisfied cease to be motivating but through deprivation are activated again and become significant. Maslow recognized individual differences in order of importance of the different needs. He also maintained that individuals are usually partially satisfied and partially unsatisfied in needs at all levels. Also, according to Maslow, most people in the society have their lower needs met. However, the satisfaction of esteem and self-actualization needs is more problematic.

Alderfer (1969) reorganized Maslow's (1954) five hierarchical levels into three levels. In his third level of motivation (ERG), Alderfer (1969) also believed that different needs may become important at different times and asserted that more than one need may be operational at any one time.

Like Maslow (1954) and Alderfer, Murray (1962) believed that conceptualization of human needs arose from clinical observations. He identified thirteen needs representing learned behaviours that can be manifested or latent according to the environmental circumstances (conditions). Murray's list includes achievement affiliation, aggression, and autonomy. These needs are, however, often in conflict. Murray (1962) does not suggest a hierarchical relationship among the needs, but since they are learned behaviour, the needs of different individuals may vary in strength and direction, both as felt and as expressed. In addition, it would seem that because the needs are learned behaviour, the list could be expanded to include a very wide range of human predisposition. To what extent the principals' administrative job enables 
him to achieve his individual and school needs will thus be a significant question.

\subsection{The two factor theory}

The two factor theory of job satisfaction was developed by Herzberg, (1959). It is based on two sets of factors thought to be present in a job; motivators and hygiene factors. The motivators include achievement, recognition, work itself, responsibility, and advancement, which are strong determinants of job satisfaction since they are effective in motivating the individual to "super performance and effort" (Herzberg, 1966).

Hygiene factors, such as company policy and administration, supervision, salary, interpersonal relations and working conditions, arise mostly from the job environment and are only involved in creating job dissatisfaction (Herzberg, 1966). Positive standing on the factors does not lead, it is held, to job satisfaction, but negative standing produce job dissatisfaction. Job satisfaction and job dissatisfaction are therefore not in one continuum but two. They are not opposites, but instead are separate dimensions of work orientation. According to Herzberg (1966), the only way to motivate an employee is to find him more challenging work in which he can assume responsibility and this is possible by making job intrinsically rewarding.

Herzberg's theory was modified by Hoy and Miskel (1992) by including a third 'ambient" factor which encompassed salary, growth possibility, risk opportunity; relationships with super ordinates and status. Research has shown that these ambient factors equally contributed to job satisfaction and job dissatisfaction (Hoy \& Miskel, 1992). In this formulation, motivators contributed more to job satisfaction than dissatisfaction. The ambient factors equally contributed to both job satisfaction and dissatisfaction. Accordingly, the effects of all these factors are not mutually exclusive as they are posited to be in Herzberg's original theory.

\subsection{Process Theories}

The expectancy theory and discrepancy theory constitute the process theories. Vroom (1964) popularized the expectancy theory which consists of four essential constructs; expectancy, valence, instrumentality and force. Expectancy is defined as "a momentary belief concerning the likelihood that a particular act will be followed by a particular outcome" (Vroom, 1964, p15). Instrumentality is the belief that a given performance is essential for attaining a given reward (Vroom, 1964, p16); and force is the directional concept used by Vroom to describe the energy or power in the behaviour which results when the strengths of the expectancy and the valence of the outcome are combined. Expectancy is therefore an actionoutcome association of behaviour with outcome connected to a second-valences and expectancies combine to determine choices.

The assumption is that choices are lawfully related to events which accompany behaviour. Vroom (1964) refers to this theory as a "cognitive" model. Motivation depends on the relative strengths of forces, which are products of valence, expectancy, and instrumentality Applying his expectancy theory to job satisfaction is strongly affected by the rewards people derive from jobs. If the rewards are positively viewed, the employee feels more satisfied with the position. If on other hand, the rewards are less than expected one feels dissatisfied with his or her job.

The discrepancy theory was developed to account for the difference in perceptions and values among individuals, and to account for the complex appraisal process through which they arrive at judgement regarding the discrepancy between what they want from their jobs and what they perceive the jobs as offering Locke (1969). Locke stressed that the causes of job satisfaction are not the job nor solely in the man but lie in the relationship between the job and the man. His theory is built on the concept of "values", which he defined as what one regards as advantageous to one's welfare. The relationship between man and the facts of reality is the foundation of those values.

Accordingly, values differ in their levels of abstraction, are hierarchical, and are dynamic in that they are subject to change as goals change. Appraisal consists of making value judgements in the process of private psychological measurement. Emotions are the psychological products of value judgements. This theory involves a comparison by individuals of what they want or expect from their job and what they actually receive. The closer the correlation between the two, the more satisfied a person is with his/her job (Locke, 1969).

In conclusion, the foregoing theories define variables for examination in any research on job satisfaction, although there is no general agreement on the determents of job satisfaction. However

\section{Research Design}

This study employed an ex-post facto research design. According to Kerlinger (1973), this is a systematic empirical 
enquiry into which the scientist does not have direct control of independent variables because their manifestations have already occurred or because they are inherently not manipulable and thus inferences about relations among variables are made without direct interventions from concomitant variations of independent and dependent variables. Supporting the above observation, Charles (1988) asserts that the cause which is the independent variable in ex-post facto research that the research cannot be manipulated because it is genetically fixed (e.g. sex, age, and race). Circumstances do not allow manipulation for example date of birth, place of birth. The cause is culturally ingrained for example, language, values, and customs.

An ex-post facto design was selected for this study because it was not possible to control independent variables of the study like age, sex, academic qualifications, administrative experience, school size and geographical location. In addition, the study was aimed at investigating the current status of the problem, that is, job factors that Principals in Kirinyaga County are dissatisfied.

\section{Overall satisfaction with the present job}

The Principals were asked to indicate their overall satisfaction with their present job. This data is presented in the table below. It shows the overall job satisfaction, value, number of respondents, percentages and cumulative percentages of the Principals

Table 50: Overall job satisfaction, value, and number of respondents, percentages and cumulative percentages

\begin{tabular}{|l|c|c|c|c|}
\hline \multicolumn{1}{|c|}{ Overall job satisfaction } & Value & $\mathbf{N}$ & $\%$ & Cumulative $\%$ \\
\hline Not satisfied & 1 & 18 & 33.3 & 33 \\
\hline Slightly satisfied & 2 & 29 & 53.7 & 87 \\
\hline Satisfied & 3 & 7 & 13 & 100 \\
\hline Very satisfied & 4 & 0 & 0 & 100 \\
\hline Extremely satisfied & 5 & 0 & 0 & 100 \\
\hline \multicolumn{1}{|c|}{ Total } & & $\mathbf{5 4}$ & $\mathbf{1 0 0}$ & $\mathbf{1 0 0}$ \\
\hline
\end{tabular}

The Table indicates that most Principals (53.7\%) were slightly satisfied with their job. However a significant portion (33.3\%) indicated that they were not satisfied with their job. The mean score and standard deviation of 1.80 and 0.66 respectively for overall job satisfaction confirm that some Principals were not satisfied with their job. Principals handle the youth in this country and if they are dissatisfied they will not render the essential services and the youth of this country would be doomed.

\section{Conclusions}

The analysis of data relating to Principals of schools in Kirinyaga District revealed important information related to job satisfaction among Principals. All conclusions from the findings of the study are made within the limitations of the study.

Data for this study was drawn from a sample of sixty Principals of whom fifty seven returned their duly completed questionnaires. The data obtained indicted that the sample consisted of 39 per cent females and 61 per cent males. Thus it can be concluded that the number of male Principals is higher than female Principals in Kirinyaga District.

Regarding academic qualification research data indicates that most of the Principals (73.7\%) in Kirinyaga District hold a Bachelor of Education (B.Ed) degree. 19.3\% of the Principals have Kenya Certificate of education /Kenya Advanced Certificate of Education with S1 qualifications while 5.2\% have East African Certificate of Education/Kenya Advanced Certificate of Education with diploma. Only one had a Master of Education degree. Thus it can be concluded that most of the Principals in the study area are well educated.

Field data revealed that of the 57 respondents 27 had administrative experience of 1-5 years and 17 had experience of 6-10 years. The two categories of administrative experience together account for over 80 per cent of all the Principals. Those Principals with over twenty years administrative experience consisted of only $7 \%$ of the respondents. Hence, it is apparent that most of the Principals in the study area did not have long administrative experience.

Research data indicates that in Kirinyaga County, $50.9 \%$ of the schools are boarding while $40.4 \%$ are day schools. Only $8.8 \%$ of the schools are both day and boarding. It is therefore apparent that most schools in the study area are boarding schools.

Regarding the size of schools in Kirinyaga County, majority of the schools have one stream (36.8\%) and two 
streams (38.6\%). $12.3 \%$ and $10.5 \%$ of the schools were made of three streams and four streams, respectively. Only one school has over five streams. It can therefore be concluded that most of the schools in the study area are small. This is because the number of streams are an indicator of the student population and therefore the size of the school.

As far as the location of the schools is concerned, majority of the schools (79.6\%) visited by the researcher were located in the rural areas. Only $20.4 \%$ of the schools are located in urban areas. This leads to the conclusion that most of the schools in Kirinyaga District are located in the rural areas.

Regarding job satisfaction among Principals in various job factor, research findings revealed that Principals were dissatisfied with job factors of remuneration $(m=1.60)$, promotion $(m=1.32)$ and job security $(m=1.50)$. They were satisfied with work content $(m=2.87)$, recognition $(m=2.33)$, working conditions $(m=2.13)$, interpersonal relations $(m=$ 2.37) and school administration $(m=2.35)$. It is apparent therefore that to improve job satisfaction in the study area, Principals' remuneration should be improved. Furthermore, promotions should be given when they are due without delay. Assurances of security of tenure of office of Principals will also go a long way in improving job satisfaction. The other job factors, namely work content, recognition, working conditions, interpersonal relations and schools administration should also be improved so as to ensure full job satisfaction among Principals.

The results $\mathrm{Ho}_{1}$ indicated there is no significant difference between job satisfaction of public secondary school Principals and their gender. It can thus be concluded that male and female Principals are at per regarding all undertakings in their employment.

According to the results from the testing of $\mathrm{Ho}_{2}$ there is no significant difference between job satisfaction of public secondary school Principals and their administrative experience. It would be expected that as Principals gain more administrative experience they show higher levels of job satisfaction. However research results would seem to indicate that there are no appreciable rewards/benefits associated with longer administrative experience in the study area.

Regarding overall job satisfaction, Principals were not satisfied with their job. A mean score of 1.80 was obtained. It can thus be concluded that Principals in Kirinyaga District are not satisfied with their job conditions.

\section{References}

Abbrev, E (1982). The Role of Self Help in the Development of Education in Kenya 1900 - 1973. Nairobi: Kenya Literature Bureau. Alderfer, C.P (1969). An Empirical Test of a New Theory of Human Needs. Organizational Behaviour and Human Performance, 4, 142 175 .

Sifuna D.N and Otiende J.E. An Introductory History of Education (1992). Nairobi.University of Nairobi Press

Andrew, F and Whitney, S(1974). Developing Measures of Perceived Life Quality: Results from Several Survey. Social Indicators Research 1. Ann Arbor, MI, Surrecy Research Centre.

Borg, G and Riding, R(1989). Educational Research: An Introduction, (5th ed.) New York: Longman,

Chapman, D.W. (1983). A model of the Influences on Teacher Retention. Journal of Teacher Education, 34, 43-49.

Charles, C.M. (1988). Introduction of Education Research. New York: Longman.

Donney, J.H. (1987) Fundamentals of Management (6 $6^{\text {th }}$ ed.). Homewood: Bp, Irwin: Britain.

Everald, B. and Morris, G. (1990) Effective School Management (2nd ed.) London: Paul Chapman Publishing Limited.

Emulole, B. and Morris, G. (1994). "Teachers Redeployment Worrying", in Daily Nation, 29th September, 1994.

Galloway, D, Boswell, C, Boswell, L. Pamkhurst, F. and Green, K.(1985). Sources of Satisfaction and Disatisfaction for Newzealand Primary School Teachers. Educational Research, 27(1), 44-51.

Gibson, S. and Dembo, M.T.T.(1984). Teacher Efficacy: A construct Validation. Journal of Educational Psychology, 1976, 569-582.

Goodlad, J.I. (1984). A place called school. Prospects of the Future. New York. Mccraw Hill.

Griffins, G. (1994) School Mastery: Straight Talk about Boarding School Management in Kenya. Lectern Publications Ltd. Nairobi.

Haezebrook, J. (1989). The effects of School Size and Leadership Styles on Teacher Job Satisfaction. (Doctoral Dissertation, Western Michigan University, 1989). Dissertation Abstracts International, 50 08A 2323.

Hahn, R.O. (1973). Creative Teachers: Who Needs Them. New York: John Wiley and Sons.

Heller, N, Clay, R. And Perkins, C (1992). Factors Related toTeacher Job Satisfaction and Dissatisfaction. ERS Spectrum, 10(1), 20-24.

Herzberg, F. Musner. B. and Syneyderman, B. (1959). The motivation to Work. New York: John Wiley.

Herzberg, F.(1966). Work and the Nature of Man. New York: World Publishing.

Hoy, W. and Miskel, C.B. (1992). Educational Admnistration: Theory Research and Practice. New York: Random House.

Imber, M. and Reyes, P. (1989). Factors contributing to teachers Job Satisfaction with participative Decision - making: In Journal of Research in Education, 23, pp. 216-225.

Keith, D. (1977).Human Behaviour at Work: Organizational Bahaviour (5th ed). New Delhi: McGraw Hill Publishing Co. Ltd.

Kerlinger, F.N. (1973). Foundation of Behavioural Research (2nd ed). New York: Holt, Rinehart and Winston Inc.

Kniveton, B. (1991). An investigation of factors contributing to Teachers' Job Satisfaction. School Pschology International, 12(4), 361 371. 
Lester, P.E. (1987). Development and Factor Analysis of the Teachers' Job Satisfaction Questionnaire (TJSQ). Educational and Psychological Measurement, 47, $223-233$.

Locke, E.A. (1969) What is Job Satisfaction? Organizational Behaviour and Human Performance, 4, 309-336.

Madera, E.A. A study of Some of the Factors Associated with Job Satisfaction/Dissatisfaction - Among Teachers in Nairobi, Kenya, Unpublished MA Thesis, University of Toronto.

Maslow, A.(1954). Motivational and Personality. New York: Harper \& Row.

Mbiti, D.M. (1994 Foundation of School Administration, Nairobi: Oxford University Press.

Mbugua, J.M. (1998). A study of Motivational Needs and Job Satisfaction of Business Studies/Teachers in Nairobi Province, Unpublished Med. Thesis University of Nairobi.

Mulusa, T. (1988). Evaluating: Education and Community Development Programmes. Nairobi: CADE, University of Nairobi and Deutsche Stiffund, For Internationals Entwicklung.

Mulusa, T. (1990). Evaluation Research for Beginners: A Practical Study Guide. Bone: German Foundation for Internatonal Develoment. Murray, H.A. (1962). Explorations in Personality. New York: Oxford University Press.

Okumbe. J.A. (1998) Educational Management: Theory and Practice. Nairobi, Nairobi University Press.

Okumbe. J.A. (1992). "Levels of Job Satisfaction Among Graduate Teachers in Secondary Schools in Siaya District and Kisumu Town" PhD Thesis, University of Nairobi.

Porter, L.W., Lawler, E.E. and Hackman, J.R (1975). Behaviour in Organizations, New York. Mccraw - Hill.

Reyes, P. and Imber, M, (1992). Teachers' Perceptions of Fairness of Their Work Load and Their Commitment, Job Satisfaction and Morale; Implications for Teacher Evaluation. Journal of Personal Evaluation in Education, 291 - 302.

Republic of Kenya (1976). Report of the National Committee on Educational Objectives and Policies. Nairobi: Government Printer.

Republic of Kenya, (1989). Development Plan, Nairobi: Government Printer.

Republic of Kenya, (1965). Kenya Education Commission Report: Nairobi: Government Printer

Republic of Kenya, (1979 - 1983). Development Plan. Nairobi: Government Printer.

Republic of Kenya, (1986). Teachers Service Commission Code of Regulations for Teachers Nairobi: Government Printer.

Republic of Kenya, (1988). Kamunge Report, Nairobi: Government Printer.

Rhodes, SR. (1983). Age Related Differences in Work Attitudes and Behaviour. Psychological Bulletin.

Rhodes - Offut, E. (1990). Job Satisfaction and Dissatisfaction Among Early Childhood Education. (Doctoral Dissertation, Arizona State? University, 1989) Dissertation Abstracts International, 50 07A 2262.

Roscoe, J.J. (1969) Fundamental Research Statistics for Behavioural Sciences. New York: Holt, Rinchart and Winston, Inc.

Rosenhottz, S.J. (1989): Workplace Conditions That Affect Teacher Quality and Commitment Implications for Teacher Induction Programs. The Elementary School Journal, 89(4), 421 - 439.

Sexton, P.(1976). Women in Education. Bloomington: Phi Delta Kappa.

Schultz, D.P. and Schultz, S.E., (1986) Phychology and Industry Today, An introduction to industrial and Organizational Psychology (4th ed.): New York: Macmillian Publishing Company.

Sogomo, C.K. (1993) "Job Satisfaction of Secondary School Principals in Rift Valley Province of Kenya" Unpublished M.Ed. Thesis. Lakehead University.

Watson, A., Hatton, G., Squires, D. and Soliman, K. (1991). School Staffing and the Quality 